University of Nebraska - Lincoln

DigitalCommons@University of Nebraska - Lincoln

Agronomy \& Horticulture -- Faculty Publications

Agronomy and Horticulture Department

2011

\title{
High-yield irrigated maize in the Western U.S. Corn Belt: I. On-farm yield, yield potential, and impact of agronomic practices
}

\author{
Patricio Grassini \\ University of Nebraska-Lincoln, pgrassini2@unl.edu \\ John Thorburn \\ Tri-Basin Natural Resources District, Holdrege, NE, tribasin@tribasinnrd.org \\ Charles Burr \\ University of Nebraska-Lincoln Phelps County Extension Office, Holdrege, NE, chuck.burr@unl.edu \\ Kenneth Cassman \\ University of Nebraska-Lincoln, kcassman1@unl.edu
}

Follow this and additional works at: https://digitalcommons.unl.edu/agronomyfacpub

Part of the Plant Sciences Commons

Grassini, Patricio; Thorburn, John; Burr, Charles; and Cassman, Kenneth, "High-yield irrigated maize in the Western U.S. Corn Belt: I. On-farm yield, yield potential, and impact of agronomic practices" (2011).

Agronomy \& Horticulture -- Faculty Publications. 585.

https://digitalcommons.unl.edu/agronomyfacpub/585

This Article is brought to you for free and open access by the Agronomy and Horticulture Department at DigitalCommons@University of Nebraska - Lincoln. It has been accepted for inclusion in Agronomy \& Horticulture -Faculty Publications by an authorized administrator of DigitalCommons@University of Nebraska - Lincoln. 


\title{
High-yield irrigated maize in the Western U.S. Corn Belt: I. On-farm yield, yield potential, and impact of agronomic practices
}

\author{
Patricio Grassini, ${ }^{1}$ John Thorburn, ${ }^{2}$ Charles Burr, ${ }^{3}$ and Kenneth G. Cassman ${ }^{1}$ \\ 1. Department of Agronomy and Horticulture, University of Nebraska-Lincoln, P.O. Box 830915, Lincoln, NE 68583-0915, USA \\ 2. Tri-Basin Natural Resources District, 1723 N Burlington, Holdrege, NE 68949, USA \\ 3. University of Nebraska-Lincoln Phelps County Extension Office, P.O. Box 2803, 2nd St., Holdrege, NE 68949-2803, USA \\ Corresponding author - K. G. Cassman, Department of Agronomy and Horticulture, University of Nebraska-Lincoln, \\ Plant Science 387, Lincoln, NE 68583-0915, USA; tel 402 472-5554, fax 402 472-7904, email kcassmanı@unl.edu
}

\begin{abstract}
Quantifying the exploitable gap between average farmer yields and yield potential $\left(Y_{\mathrm{P}}\right)$ is essential to prioritize research and formulate policies for food security at national and international levels. While irrigated maize accounts for $58 \%$ of total annual maize production in the Western U.S. Corn Belt, current yield gap in these systems has not been quantified. Our objectives were to quantify $Y_{\mathrm{P}}$, yield gaps, and the impact of agronomic practices on both parameters in irrigated maize systems of central Nebraska. The analysis was based on a 3-y database with field-specific values for yield, applied irrigation, and $\mathrm{N}$ fertilizer rate $(n=777) . Y_{\mathrm{P}}$ was estimated using a maize simulation model in combination with actual and interpolated weather records and detailed data on crop management collected from a subset of fields $(n=123)$. Yield gaps were estimated as the difference between actual yields and simulated $Y_{\mathrm{P}}$ for each field-year observation. Long-term simulation analysis was performed to evaluate the sensitivity of $Y_{\mathrm{P}}$ to changes in selected management practices. Results showed that current irrigated maize systems are operating near the $Y_{\mathrm{P}}$ ceiling. Average actual yield ranged from 12.5 to $13.6 \mathrm{Mg} \mathrm{ha}^{-1}$ across years. Mean $\mathrm{N}$ fertilizer efficiency (kg grain per $\mathrm{kg}$ applied $\mathrm{N}$ ) was $23 \%$ greater than average efficiency in the USA. Rotation, tillage system, sowing date, and plant population density were the most sensitive factors affecting actual yields. Average yield gap was $11 \%$ of simulated $Y_{\mathrm{P}}\left(14.9 \mathrm{Mg} \mathrm{ha}^{-1}\right)$. Time trends in average farm yields from 1970 to 2008 show that yields have not increased during the past 8 years. Average yield during this period represented $\sim 80 \%$ of $Y_{\mathrm{P}}$ ceiling estimated for this region based on current crop management practices. Simulation analysis showed that $Y_{\mathrm{P}}$ can be increased by higher plant population densities and by hybrids with longer maturity. Adoption of these practices, however, may be constrained by other factors such as difficulty in planting and harvest operations due to wet weather and snow, additional seed and grain drying costs, and greater risk of frost and lodging. Two key points can be made: (i) irrigated maize producers in this region are operating close to the $Y_{\mathrm{P}}$ ceiling and achieve high levels of $\mathrm{N}$ use efficiency and (ii) small increases in yield $(<13 \%)$ can be achieved through fine tuning current management practices that require increased production costs and higher risk.
\end{abstract}

Keywords: Zea mays L., maize, yield potential, on-farm yield, exploitable yield gap, simulation model

\section{Introduction}

Yield potential $\left(Y_{\mathrm{p}}\right)$ is defined as the yield of a crop cultivar when grown in an environment to which it is adapted, with nutrient and water non-limiting and pests and diseases effectively controlled (Loomis and Connor, 1992; Evans, 1993). Thus, $Y_{\mathrm{p}}$ is determined by genotype, plant population density and uniformity, and location-specific solar radiation and temperature regimes. The difference between on-farm yield and $Y_{\mathrm{p}}$ represents the exploitable yield gap (Cassman et al., 2003; Lobell et al., 2009). As farmer's yields approach $Y_{\mathrm{p}}$ (i.e., diminishing exploitable yield gap), it becomes more difficult for farmers to sustain yield in- creases because further gains require the elimination of small imperfections in management of the crop system which is usually not economically viable. Hence, plateaus in yield time trends typically occur when average farm yields reach about $80 \%$ of $Y_{\mathrm{P}}$ as was first observed in irrigated rice systems in Asia, although this value may change across regions due to differences in the ratio of grain to input prices and access to cost-effective technologies (Cassman, 1999; Lobell et al., 2009). Accurate estimation of current exploitable gaps in major cropping systems of the world is therefore essential to estimate future food production capacity and help to formulate policies and research to ensure local and global food security. 


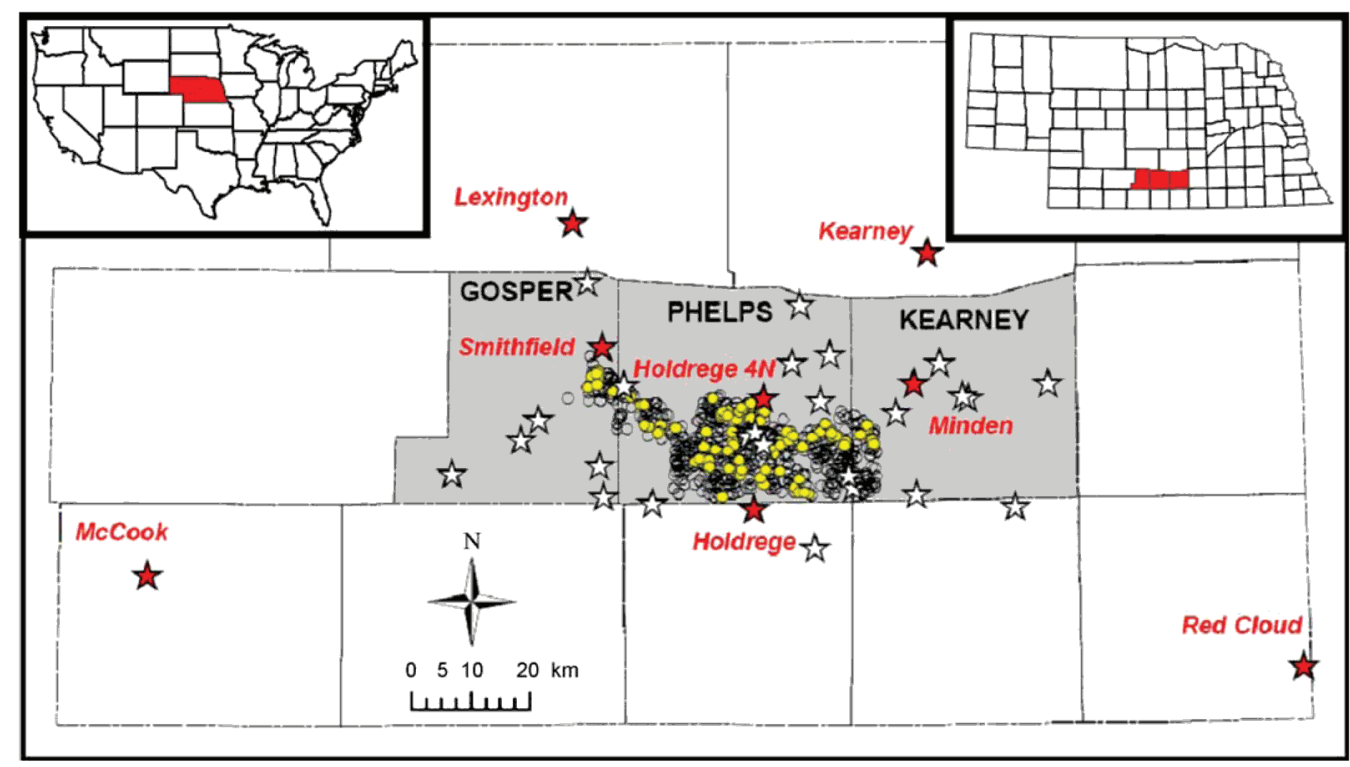

Figure 1. Map of south-central Nebraska showing the location of the Tri-Basin Natural Resources District (NRD; shaded area). Empty circles indicate location of the 521 fields included on the database; solid circles show location of those fields with additional data on crop management. Stars indicate location of rain gauges $(n=33)$; solid stars indicate location of meteorological stations used for interpolation of daily incident solar radiation, temperature, relative humidity, and reference evapotranspiration $(n=8$; names are shown in italic). Lines show county boundaries; Tri-Basin NRD counties are named. Location of Tri-Basin NRD within Nebraska and Nebraska within contiguous U.S. is shown (right and left insets, respectively).

Although maize production must increase substantially to meet the rapidly increasing demand for food, livestock feed, and biofuel at a global scale (Cassman et al., 2003; Cassman and Liska, 2007), little increase in maize $Y_{\mathrm{P}}$ has been observed during the last 30 years (Duvick and Cassman, 1999; Tollenaar and Lee, 2002). The Western U.S. Corn Belt $\left(37^{\circ} \mathrm{N}-45^{\circ} \mathrm{N} ; 92^{\circ} \mathrm{W}-\right.$ $105^{\circ} \mathrm{W}$ ) includes one of the largest irrigated areas cultivated with maize in the world ( 3.2 million ha) mostly located in Kansas, Nebraska, and South Dakota states (USDA-NASS, 2003-2008). Irrigated maize represents $43 \%$ of the total maize area (70\% of the total irrigated cropland in the Western Corn Belt) and accounts for $58 \%$ of the total annual maize production of 60 million $\mathrm{Mg}$ in this region. Duvick and Cassman (1999) reported Nebraska state-level yield to be approximately 50\% below the $Y_{\mathrm{p}}$ estimated from reported contest-winning yield levels (18.2 $\left.\mathrm{Mg} \mathrm{ha}^{-1}\right)$. Farmers who win these contests, however, use practices that are not likely to be economically viable or environmentally sustainable when practiced on a commercial scale. Likewise, average $Y_{\mathrm{p}}$ may be smaller than contest-winning yields because winning yields come from the most favorable combination of soil, weather, and crop management over a large geographic area. For example, Grassini et al. (2009) estimated average $Y_{\mathrm{P}}$ to range between 11.4 and $16.1 \mathrm{Mg} \mathrm{ha}^{-1}$ across 18 locations in the Western U.S. Corn Belt based on simulation modelling using 20 years of weather records and site-specific management. Hence, the magnitude of the exploitable yield gap has not been accurately quantified based on the current management of maize systems.

Lack of data from well-designed experiments in which yieldlimiting factors have been effectively controlled makes it difficult to obtain reliable quantifications of $Y_{\mathrm{p}}$ based on actual measurements (Duvick and Cassman, 1999). Simulation models can provide reasonable estimates of $Y_{\mathrm{p}}$ when soil and historical daily weather data are available (Abeledo et al., 2008; Lobell et al., 2009). Data collected from farmer's fields can be used to evaluate actual productivity and identify major limitations in crop systems (e.g., Mercau et al., 2001; Sadras et al., 2002; Lobell et al., 2005). Because these studies lack an explicit experimental design and specific hypotheses, it is difficult to establish causal relationships although sensitive factors associated with productivity can be identified (Wiese, 1982; Sadras et al., 2002).
Given the paucity of measured data that can benchmark average farm yields against $Y_{\mathrm{p}}$, we explored the use of on-farm crop yield and management data with simulation modelling to assess actual and potential productivity of high-yield irrigated maize systems. Specific objectives of the present study were to: (i) provide a description of current management practices in irrigated maize systems using a large database collected from farmer's fields in central Nebraska (USA), (ii) quantify the existing gap between actual yield and $Y_{\mathrm{P}}$ using on-farm data and simulation analysis, and (iii) assess the impact of agronomic practices on on-farm yield and $Y_{\mathrm{P}}$.

\section{Materials and methods}

\subsection{Tri-Basin Natural Resources District (NRD)}

State law divides Nebraska into 23 natural resources districts (NRDs), each serving as a local government entity with authority to establish regulations and incentives to protect and conserve natural resources within the district (Nebraska Association of Resources Districts, 2010). Each NRD sets its own priorities and develops its own programs to best serve local needs. The Tri-Basin NRD (Tri-Basin Natural Resources District, 2010) includes Gosper, Phelps, and Kearney counties in central Nebraska (Figure 1). Total cropland area (excluding crops for silage and forages) in these three counties is approximately 250,000 ha (USDA-NASS, 2001-2008). Major crops are maize and soybean (61 and 33\% of total cropland area, respectively) with 87 and 9o\% of the land area planted with these crops under irrigation. There are 6244 active registered groundwater wells for agricultural use in the area (Nebraska DNR, 2010). Average well and pumping depths are 58 and $34 \mathrm{~m}$, respectively. Average rainfed yields for maize and soybean in the Tri-Basin NRD three-county region are 5.2 and 2.2 $\mathrm{Mg}^{-1}$, respectively, and 12.1 and $3.9 \mathrm{Mg} \mathrm{ha}^{-1}$ with irrigation (USDA-NASS, 2001-2008). Average maize yield with irrigation is similar to the Nebraska state-level irrigated average yield (11.9 $\mathrm{Mg} \mathrm{ha}^{-1}$ ). Maize production in the Tri-Basin NRD $(\approx 1.7$ million $\mathrm{Mg}$ ) is highly dependant on irrigated maize, which represents $94 \%$ of total production. 


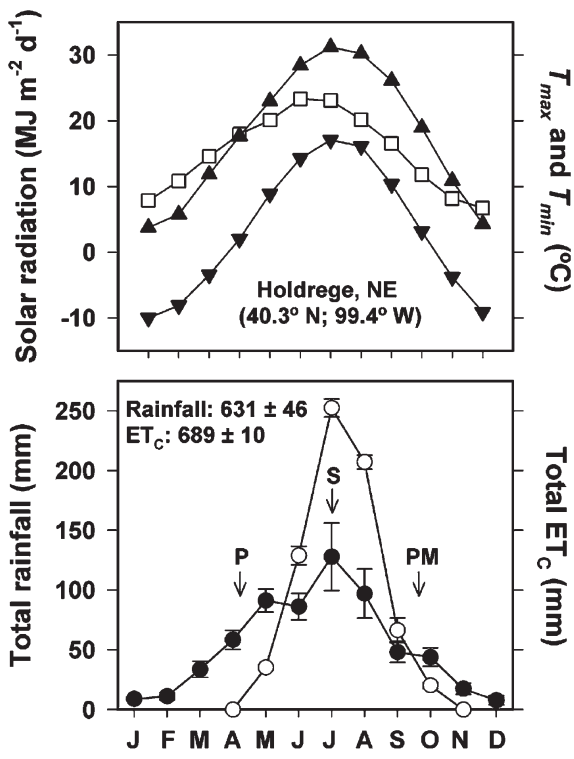

Figure 2. Monthly values for average total incoming solar radiation (口), maximum and minimum temperature $\left(T_{\max }[\mathbf{\Delta}]\right.$ and $T_{\min }[\mathbf{\nabla}]$, respectively), total rainfall $(\bullet)$, and crop evapotranspiration under non-limiting water supply $\left(\mathrm{ET}_{\mathrm{C}}[\mathrm{O}]\right)$ in Tri-Basin Natural Resources District based on 20-year (1988-2008) weather records from Holdrege (see Figure 1). ET $_{C}$ simulated using Hybrid-Maize model for maize crops with average management practices (sowing date: DOY 117 , relative maturity: $113 \mathrm{~d} ; 7.2$ plants $\mathrm{m}^{-2}$ ). Error bars indicate $\pm \mathrm{SE}$ of the mean. Arrows in bottom panel indicate average dates of planting $(\mathrm{P})$, silking $(\mathrm{S})$, and physiological maturity $(\mathrm{PM})$. Annual average $( \pm \mathrm{SE})$ total rainfall and $\mathrm{ET}_{\mathrm{C}}$ are shown.

The area inside the Tri-Basin NRD has flat to rolling terrain. Soils suitable for maize production are mapped in the Holdrege and, to a lesser extent, the Coly, Detroit, Hobbs, Kenesaw, and Uly series (USDA-NRCS). All series have silt loam texture. Available soil water-holding capacity in the root zone $(\mathrm{o}-1.5 \mathrm{~m})$ ranges from 230 to $320 \mathrm{~mm}$. None of the soils have physical impediments to root growth under typical production conditions. Annual patterns of radiation, temperature, rainfall, and crop evapotranspiration $\left(\mathrm{ET}_{\mathrm{C}}\right)$ in Tri-Basin NRD are shown in Figure 2. Rainfall distribution follows a monsoonal pattern: $70 \%$ is concentrated in the maize growing season. $\mathrm{ET}_{\mathrm{C}}$ peaks in July and August, which is coincident with silking and early grain-filling crop stages. Total water deficit, estimated as difference between rainfall and $\mathrm{ET}_{\mathrm{C}}$ during growing season is $253 \pm 47 \mathrm{~mm}$, well above water deficit estimated for other more favorable locations in U.S. Corn Belt such as Ames, Iowa ( $32 \pm 44 \mathrm{~mm}$ ). Hence, maize crops grown in Tri-Basin NRD depend strongly on irrigation water and stored soil moisture that accumulates from snow melt and spring rains.

\subsection{Database description and analysis}

Farmers in the Tri-Basin NRD must report data on certain management practices used on each of their irrigated fields. Included in this NRD databases are geographic coordinates, grain yield (at standard moisture content of $0.155 \mathrm{~kg} \mathrm{H}_{2} \mathrm{O} \mathrm{kg}$-1 grain), previous crop, and amount of nitrogen (N) fertilizer applied. There are three basins within the Tri-Basin NRD: Little Blue, Platte, and Republican. Farmers in the Republican Basin must also report type of irrigation system and amount of irrigation water applied during crop growing-season based on flow meter readings. For the current study, we used data from 521 commercial irrigated maize fields (mean size: 46 ha) in the Republican Basin from 2005 to 2007 (Figure 1). Some fields were included in more than one year, so our analysis included a total of 777 field-year observations. Each field was planted, managed, and (mechanically) harvested as a unit.

Data on crop management (sowing date, seeding rate, hybrid name and relative maturity $[\mathrm{RM}]^{1}$, and tillage system) and adversities (incidence of insects, pests, diseases, hail, lodging, green snap, and lack of stand uniformity) were collected from a subset of 123 field-years through mail survey, phone, and personal interviews (Figure 1). Incidence of crop adversities was based on farmer's visual inspection and records. Two-tailed $t$-tests were performed separately for each year and showed no difference in grain yield, applied irrigation, or rate of $\mathrm{N}$ fertilizer between the 777 field-year database and the subset of 123 field-years $(p>0.20)$, except in 2006 when yield in the subset was slightly higher $(3 \%, p=0.04)$ than in the complete database. Thus, similarity in yield and applied inputs indicate the 123 field-year subset is representative of the larger database.

A variety of analytical methods are available to describe and analyze on-farm data as reviewed by Wiese (1982). In the present study, frequency distributions were calculated to illustrate the range of variation and probabilities associated with actual yield and crop management practices. Two approaches were used to assess causes of yield variation due to management factors: (i) regression analysis and (ii) comparison of factors means measured in the highest- vs. lowest-yielding field classes (determined from the upper and lower yield terciles, respectively, on each year) using a two-tailed $t$-test or Wilcoxon test when distribution of observed values deviated from normality. To investigate interactions between sowing date and hybrid maturity, crops were classified into four sowing date interval categories (day of year [DOY] 105-113, 114-120, 121-127, and 128-135) and two RM categories ("short"-[RM 106-112 d] and "full-season" hybrids [RM 113-118 d). Short- and full-season hybrids were equally represented across the four sowing intervals.

\subsection{Simulation analysis}

The Hybrid-Maize model (Yang et al., 2004, 2006) was used to simulate $Y_{\mathrm{P}}$ for the subset of crops that included data on actual sowing date, hybrid brand and RM, and seeding rate $(n=123)$. Hybrid-Maize is a process-oriented model that simulates maize development and growth on a daily time-step under growth conditions without limitations from nutrient deficiencies or toxicities, or from insect pests, diseases, and weeds. It features temperature-driven maize development, vertical canopy integration of photosynthesis, organ-specific growth respiration, and temperature-sensitive maintenance respiration. Validation of Hybrid-Maize has shown to be robust and reasonably accurate in estimating maize yields in field studies across a wide range of environments in the U.S. Corn Belt where the crop was managed under near optimal conditions (Yang et al., 2004; Grassini et al., 2009). Daily values of radiation and maximum and minimum temperature are required to simulate $Y_{\mathrm{p}}$ with this model. Thus, synthetic weather files were assembled for each of the 123 field-years with data on crop management. A modified inverse distance weight method proposed by Franke and Nielson (1980) was used to interpolate daily values of incident solar radiation and maximum and minimum temperature from meteorological stations located inside or near the Tri-Basin NRD $(n=8$; Figure 1). Density and distribution of meteorological stations were adequate to describe geospatial patterns of radiation and temperature (Hubbard, 1994). Simulations used actual sowing date, hybrid brand and RM, and plant population reported for each field-year observation. Hybrid-Maize requires effective plant population density, thus, the latter was assumed to be $94 \%$ of actual seeding rate as suggested by Yang et al. (2006). Yield gap for each field-year was calculated as the difference between actual reported yield from the NRD database and simulated $Y_{\mathrm{P}}$. 

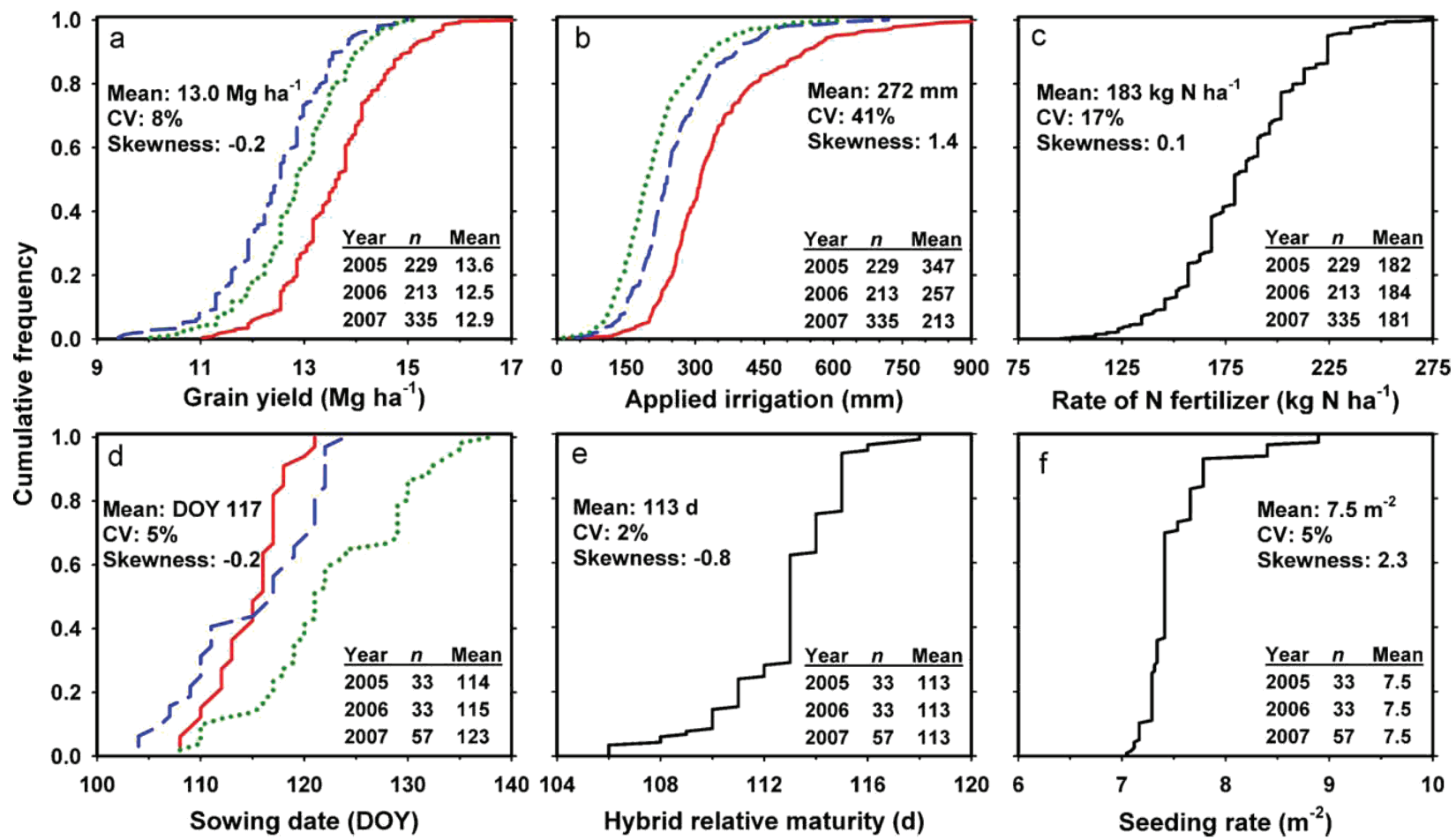

Figure 3. Cumulative frequency distributions of actual (a) grain yield, (b) applied irrigation, (c) rate of N fertilizer, (d) sowing date, (e) hybrid relative maturity, and (f) seeding rate collected from irrigated maize fields in the Tri-Basin Natural Resources District (NRD) during 2005 (-), 2006 (- -), and 2007 (- - ) seasons. Effect of year on rate of N fertilizer, hybrid maturity, and seeding rate was not significant $(p>0.65)$; thus, data were pooled across years. Mean values for each year are shown. Data for yield, irrigation, and N fertilizer rate came from the Tri-Basin NRD database with 777 field-year observations. Data for sowing date, hybrid maturity, and seeding rate were obtained from a subset of 123 field-year observations.

Opportunities to increase $Y_{\mathrm{p}}$ by changing current crop management were investigated using Hybrid-Maize in combination with daily radiation and temperature records from four meteorological stations inside or near the Tri-Basin NRD. One weather station (Holdrege) had weather records from 1988 to 2008 period; the other three weather stations (Holdrege $4 \mathrm{~N}$, Minden and Smithfield) had records from 1996 to 2008 period (Figure 1). Change in mean $Y_{\mathrm{p}}$ at Holdrege when simulations used weather records from 1988 to 2008 instead of 1996-2008 interval was negligible $(<0.5 \%)$; thus, $Y_{\mathrm{P}}$ at Holdrege was estimated using 1988-2008 weather record series. A representative combi- nation of current average farmer management practices from the subset of 123 field-year observations (sowing date: DOY 117, RM $113 \mathrm{~d}, 7.2$ plants $\mathrm{m}^{-2}$ ) was taken as a baseline to evaluate $Y_{\mathrm{p}}$ response to changes in sowing date $(-7,+7$, and $+14 \mathrm{~d})$, RM $(-4$ and $+4 \mathrm{~d})$, and plant population $\left(+0.7,+1.4\right.$ plants $\left.\mathrm{m}^{-2}\right)$ resulting in 36 sowing date $\times$ RM $\times$ plant population combinations. Sign and magnitude of these changes were representative of the actual range of management practices used by farmers in the 123 field-year subset. Average $Y_{\mathrm{p}}$ for each of the 36 combinations was calculated by averaging the mean $Y_{\mathrm{P}}$ calculated using weather records from the four weather stations. Additionally, time trends

Table 1. Average $( \pm \mathrm{SE})$ total incoming solar radiation, maximum $\left(T_{\max }\right)$ and minimum $\left(T_{\min }\right)$ temperatures, total rainfall, and total reference evapotranspiration (ET ; FAO-Penman-Monteith) computed for the entire crop cycle (ECC), or the pre-silking (Pre-S), around-silking (S), and post-silking (PostS) phases of maize crops grown in the Tri-Basin Natural Resources District (NRD) during the 2005-2007 seasons. 12-y means for the ECC are also shown.

\begin{tabular}{|c|c|c|c|c|c|c|}
\hline Season & Crop phase ${ }^{a}$ & Solar radiation $\left(\mathrm{MJ} \mathrm{m} \mathrm{m}^{-2} \mathrm{~d}^{-1}\right)$ & $T_{\max }\left({ }^{\circ} \mathrm{C}\right)$ & $T_{\min }\left({ }^{\circ} \mathrm{C}\right)$ & Rainfall (mm) & $\mathrm{ET}_{\mathrm{O}}(\mathrm{mm})$ \\
\hline \multirow[t]{4}{*}{2005} & Pre-S & $20.7 \pm 0.3^{b}$ & $24.0 \pm 0.2$ & $10.5 \pm 0.3$ & $227 \pm 6$ & $448 \pm 4$ \\
\hline & S & $23.2 \pm 0.6$ & $32.1 \pm 0.5$ & $17 \cdot 9 \pm 0.1$ & $26 \pm 4$ & $198 \pm 9$ \\
\hline & Post-S & $20.1 \pm 0.4$ & $29.2 \pm 0.3$ & $15.6 \pm 0.1$ & $113 \pm 9$ & $259 \pm 9$ \\
\hline & $\mathrm{ECC}$ & $21.0 \pm 0.4$ & $27.2 \pm 0.3$ & $13.6 \pm 0.2$ & $366 \pm 13$ & $906 \pm 22$ \\
\hline \multirow[t]{4}{*}{2006} & Pre-S & $23.4 \pm 0.3$ & $26.5 \pm 0.1$ & $11.2 \pm 0.1$ & $179 \pm 14$ & $510 \pm 3$ \\
\hline & $\mathrm{S}$ & $24.2 \pm 0.4$ & $31.0 \pm 0.2$ & $17.1 \pm 0.1$ & $59 \pm 9$ & $189 \pm 5$ \\
\hline & Post-S & $20.3 \pm 0.5$ & $29.1 \pm 0.3$ & $16.3 \pm 0.1$ & $148 \pm 29$ & $252 \pm 9$ \\
\hline & ECC & $22.5 \pm 0.4$ & $28.2 \pm 0.2$ & $14.0 \pm 0.1$ & $386 \pm 31$ & $952 \pm 15$ \\
\hline \multirow[t]{4}{*}{2007} & Pre-S & $22.1 \pm 0.5$ & $25.2 \pm 0.1$ & $13.0 \pm 0.2$ & $225 \pm 23$ & $377 \pm 1$ \\
\hline & $\mathrm{S}$ & $23.8 \pm 0.4$ & $30.8 \pm 0.4$ & $17.6 \pm 0.2$ & $53 \pm 13$ & $175 \pm 7$ \\
\hline & Post-S & $19.2 \pm 0.4$ & $30.1 \pm 0.3$ & $18.2 \pm 0.1$ & $153 \pm 12$ & $227 \pm 11$ \\
\hline & ECC & $21.5 \pm 0.4$ & $28.0 \pm 0.2$ & $15 \cdot 7 \pm 0.2$ & $431 \pm 27$ & $779 \pm 17$ \\
\hline 12-y mean & ECC & $20.8 \pm 0.2$ & $27.4 \pm 0.3$ & $13.9 \pm 0.1$ & $392 \pm 12$ & $907 \pm 16$ \\
\hline
\end{tabular}

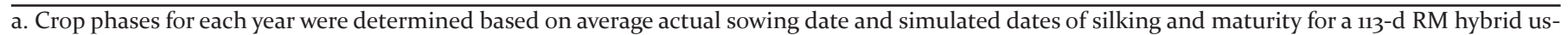
ing Hybrid-Maize model. Silking (S) phase includes the interval from -14 to $7 \mathrm{~d}$ around silking

b. Each value is the average of four weather stations inside or near the Tri-Basin NRD (Holdrege, Holdrege 4 N, Minden, and Smithfield). 
in Tri-Basin NRD (3-county average) irrigated yields reported by USDA-NASS were compared against average $Y_{\mathrm{P}}$ simulated for the 1988-2008 period using current average farmer management practices (sowing date: DOY 117, RM $113 \mathrm{~d}, 7.2$ plants $\mathrm{m}^{-2}$ ).

\section{Results \\ 3.1. Actual productivity and management of irrigated maize systems in central Nebraska}

Farmer's grain yields were normally distributed and had a relatively small degree of variation for production-scale data, which attest to both the high degree of farmer management skills and the favorable environment for irrigated maize production (Figure $3 \mathrm{a})$. Mean $3-y$ yield was slightly above $(\approx 5 \%)$ the Tri-Basin 3-county irrigated average yield (12.3 $\mathrm{Mg} \mathrm{ha}^{-1}$; USDA-NASS, $2005^{-2007)}$. The effect of year on grain yield was significant $(p<0.001)$ : average and maximum yields were lower in 2006 and 2007 compared with those reported in 2005 . This reduction in yield was presumably due to an episode of very high temperature and low relative humidity immediately after silking in 2006 (data not shown) and higher night temperatures combined with low radiation during the post-silking phase in 2007 (Table 1; see also Section 3.3). No geospatial pattern in grain yield was observed in any of the years (data not shown).

Frequency distribution of applied irrigation deviated from normality because $15-20 \%$ of the fields in each year received a much larger amount of applied water than other fields (Figure $3 \mathrm{~b})$. Effect of year on irrigation was significant $(p<0.001)$. Average applied irrigation decreased from 2005 to 2007, and this trend was associated with higher rainfall and lower evaporative demand during the silking and post-silking phases (Table 1). Irrigation was applied by center pivot sprinklers, surface gravity (mostly gated-piped furrows), or a combination of both irrigation systems $(49,33$, and $18 \%$ of the total fields, respectively). The latter category involves a center pivot that typically covers $>85 \%$ of total field area coupled with surface irrigation in field corners. Main energy sources for irrigation systems are natural gas, diesel, and electricity (49, 26, and $21 \%$, respectively). Most farmers $(\approx 70-75 \%)$ rely on crop consultants to determine amount and timing of irrigation events. Irrigations are typically scheduled based on soil water content, water balance computations, and type of irrigation system. A thorough analysis of irrigation management and efficiency is discussed in a separate paper (Grassini et al., 2011).

Average rates of $\mathrm{N}$ fertilizer in the Tri-Basin NRD dataset did not differ among years or irrigation system ( $p=0.66$; Figure 3c). Mean $\mathrm{N}$ fertilizer rate in maize grown after soybean was $21 \mathrm{~kg} \mathrm{~N} \mathrm{ha}^{-1}$ less than when maize followed maize $(p<0.001)$ while $\mathrm{N}$ rates were similar across tillage systems $(p>0.40)$. Most $\mathrm{N}$ fertilizer was incorporated before sowing (70-90\%); the rest was applied as a side-dressing or fertigation during the crop growing season. Over the last 10 years, anhydrous ammonia has been gradually replaced by urea-ammonium-nitrate solution (UAN), and these two forms account for approximately $70-80 \%$ of total $\mathrm{N}$ fertilizer applied in commercial maize fields in the Tri-Basin NRD (USDA-NASS, 1999-2008). Although mean N rate on irrigated maize in the Tri-Basin was considerably greater than the Nebraska state average (182 vs. $152 \mathrm{~kg} \mathrm{~N} \mathrm{ha}^{-1}$ ), $\mathrm{N}$ fertilizer use efficiency ( $\mathrm{kg}$ grain per $\mathrm{kg} \mathrm{N}$ fertilizer applied) was also much higher than $\mathrm{Ne}-$ braska state average ( $71 \mathrm{vs} .64 \mathrm{~kg}_{\text {grain }} \mathrm{kg}^{-1} \mathrm{~N}$ fertilizer).

Sources of indigenous $\mathrm{N}$ supply include residual soil inorganic $\mathrm{N}$, net $\mathrm{N}$ mineralization from soil organic matter and residues, and $\mathrm{N}$ inputs from atmospheric deposition and irrigation water. Based on measured plant $\mathrm{N}$ accumulation in replicated on-farm plots that did not receive $\mathrm{N}$ fertilizer, the contribution of indigenous $\mathrm{N}$ supply to irrigated maize in Tri-Basin NRD is about $145 \mathrm{~kg} \mathrm{~N} \mathrm{ha}^{-1}$, as measured in the study of Dobermann et al. (2006), which is consistent with values of indigenous $\mathrm{N}$ supply reported for U.S. Corn Belt (Cassman et al., 2002). Average N fertilizer uptake efficiency, calculated as the ratio of ( $\mathrm{N}$ accumulation at farmers average yield level minus $\mathrm{N}$ uptake in non-fertilized plots) to applied $\mathrm{N}$ fertilizer, is $0.40 \mathrm{~kg} \mathrm{~N}$ uptake per $\mathrm{kg} \mathrm{N}$ supply. In the previous calculation, $\mathrm{N}$ accumulation in aboveground biomass for average yield reported by farmers in this study (13.0 $\mathrm{Mg} \mathrm{ha}^{-1}$ ) was derived from the generic relationship between maize grain yield and $\mathrm{N}$ uptake following Cassman et al. (2002). Phosphorus $(\mathrm{P})$ fertilizer is typically applied before planting at a rate of about $25 \mathrm{~kg} \mathrm{P} \mathrm{ha}^{-1}$. Potassium fertilizer is rarely applied to maize in the Tri-Basin NRD because soil tests usually indicate adequate supply of this nutrient.

Most common crop sequences were maize after soybean and continuous maize (61 and $38 \%$, respectively). A small proportion of maize ( $1 \%)$ was sown after wheat. No-till, ridge-till, disk, and strip-till accounted for $37,31,22$, and $10 \%$ of the crops, respectively. Crop sequences and tillage systems were equally represented across years. Data on sowing date, RM and seeding rate collected from a subset of 123 field-years are summarized in Figures $3 \mathrm{~d}-\mathrm{f}$. Frequency distributions for these parameters did not deviate from normality except for seeding rate. While RM and seeding rates were not different across years $(p>0.80)$, maize sowing in 2007 was later than in 2005 and 2006 (DOY 123 vs. 114 and 115 , respectively) due to intense rainfall between DOY 112 and DOY 115. Average farmer's seeding rate in the Tri-Basin NRD ( 7.5 seeds $\mathrm{m}^{-2}$ ) is below the range of plant population densities that gives highest yields in the region $\left(8-10\right.$ plants $\left.\mathrm{m}^{-2}\right)$ as reported in several studies (Yang et al., 2004; Verma et al., 2005; Grassini et al., 2009). We suspect that economic optimum for plant population density is significantly below the biophysical optimum for highest yield because seed costs in irrigated maize systems represent $\sim 25 \%$ of total variable production costs in $\mathrm{Ne}$ braska (Klein and Wilson, 2010).

About $75 \%$ of the maize fields during the 2005-2007 seasons were planted with hybrids possessing one or more transgenic trait, including Bt insect control, herbicide tolerance, or both $(36,22$, and $17 \%$ of the total maize land area, respectively; USDA-ERS). Therefore, insecticide application was very low on transgenic hybrids and most applications were made to fields and refuge areas planted with non-transgenic hybrids. Weed control was performed with herbicides and/or cultivation. Fungicides are rarely applied to maize in the relatively dry Western U.S. Corn Belt because incidence and severity of diseases rarely justify treatment.

\subsection{Impact of management practices on actual yield}

Crop sequence and tillage system have significant effects on grain yield $(p<0.001)$. Data contained in the 777 field-year database revealed that maize after soybean produced $0.5 \pm 0.1 \mathrm{Mg} \mathrm{ha}^{-1}$ more than maize after maize, which was consistent across years (Figure 4a). The subset of fields with more detailed management indicated a significant crop sequence $\times$ tillage interaction on grain yield $(p<0.005)$ : while yield was not affected by tillage when maize followed soybean, maize yield following maize was smaller in ridge- and no-till compared to disk (Figure 4b). Yield advantage of maize/soybean rotation over continuous maize was only significant in no-tilled crops.

Regression analysis and two-tailed $t$-test comparison of highest- and lowest-yield field classes showed a significant effect of sowing date, seeding rate, and in a lesser degree, RM on actual yields (Table 2). In general, highest-yield fields were observed with early sowing (DOY 107-120) and high seeding rates $\left(>7.5\right.$ seeds $\left.\mathrm{m}^{-2}\right)$. A small advantage of full- over short-season hybrids $\left(\approx 0.3 \mathrm{Mg} \mathrm{ha}^{-1}\right)$ was consistent in the first three sowing intervals (DOY 105-127). This trend reversed (-0.2 $\left.\mathrm{Mg} \mathrm{ha}^{-1}\right)$ in the last interval (DOY 128-135) probably due to greater incidence of a 
Table 2. Coefficients $( \pm \mathrm{SE})$ of linear regressions between actual yield $\left(\mathrm{Mg} \mathrm{ha}^{-1}\right)$ and a series of management factors. Data were pooled across years. Quadratic effects were not significant. Factors means for lowest- (LY) and highest-yield fields (HY) are also shown (average yield: 12.1 and 13.9 Mg ha $^{-1}$, respectively); the difference $(\Delta)$ was tested by a two-tailed $t$-test or Wilcoxon test when distribution deviated from normality.

\begin{tabular}{|c|c|c|c|c|c|c|}
\hline \multirow[t]{2}{*}{ Management factor } & \multirow[t]{2}{*}{ Intercept $\left(\mathrm{Mg} \mathrm{ha}^{-1}\right)$} & \multirow[t]{2}{*}{ Slope } & \multirow[t]{2}{*}{ Pearson $r$} & \multicolumn{3}{|c|}{ Factors means } \\
\hline & & & & $L Y^{a}$ & $\mathrm{HY}^{\mathrm{a}}$ & $\Delta$ \\
\hline Planting date (day of year) & $17.1 \pm 1.3$ & $-0.03 \pm 0.01 \mathrm{Mg}$ per day & $-0.32^{* *}$ & 119 & 115 & $4^{* *}$ \\
\hline Hybrid relative maturity (days) & $5 \cdot 9 \pm 3.8$ & $0.06 \pm 0.03 \mathrm{Mg}$ per day & $0.17^{*}$ & 112 & 114 & $2^{*}$ \\
\hline $\mathrm{N}$ fertilizer rate $\left(\mathrm{kg} \mathrm{N} \mathrm{ha}^{-1}\right)$ & $14.1 \pm 0.5$ & $-0.005 \pm 0.003 \mathrm{Mg}$ per $\mathrm{kg} \mathrm{N}$ & 0.15 & 187 & 182 & 5 \\
\hline Applied irrigation (mm) & $12.7 \pm 0.2$ & $0.001 \pm 0.001 \mathrm{Mg}$ per $\mathrm{mm}$ & $0.26^{*}$ & 224 & 271 & 47 \\
\hline
\end{tabular}

a. Lowest- and highest-yield categories based on pooling fields in the lower and upper tercile of the yield frequency distribution across years, respectively.

* Significance at $p<0.05 ; * *$ Significance at $p<0.01 ;{ }^{* * *}$ Significance at $p<0.001$

frost event before physiological maturity in full-season hybrids. Data analysis also revealed that yield was poorly related to the rate of $\mathrm{N}$ fertilizer and amount of applied irrigation. Although frequency of fields reported by farmers to have been affected by diseases, weeds, insects, hail damage, lodging, green snap or lack of stand uniformity was not negligible (10, 15, and $25 \%$ in 2005, 2006, and 2007 seasons, respectively), there was no correlation between incidence of these constraints and yield. We suspect that farmers reported these occurrences even when a relatively small portion of the field was affected.

\subsection{Yield gaps and opportunities for increasing yield poten- tial through crop management}

There was a significant effect of year $(p<0.001)$ on simulated $Y_{\mathrm{P}}$, yield gap, and the ratio of actual yield to $Y_{\mathrm{P}}$ (Figure 5a-c). Average $Y_{\mathrm{P}}$ in 2007 (14.2 $\mathrm{Mg} \mathrm{ha}^{-1}$ ) was lower than in 2005 and 2006 (15.3 and $15.1 \mathrm{Mg} \mathrm{ha}^{-1}$, respectively). The late sowing date in $2007 \mathrm{ex}^{-}$ posed crops to low solar radiation during the post-silking phase

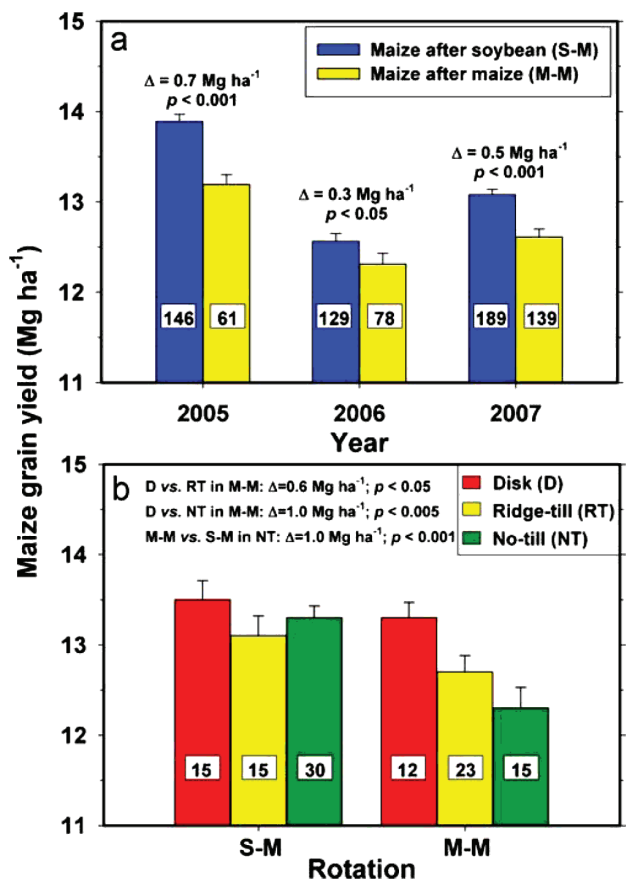

Figure 4. Average $( \pm$ SE) maize yield in fields (a) under different rotation (maize after maize and maize after soybean) during the 2005-2007 seasons and (b) under disk, ridge-, and no-till systems. Tillage systems were equally represented across years, thus, data were pooled across years in (b). Rotation $\times$ tillage interaction was significant $(p<0.005)$. Difference $(\Delta)$ and $t$-test significance for selected comparisons between rotations or tillage systems are shown. Numbers inside bars indicate number of observations. A small proportion of crops under strip-till or sown after wheat was not include in this analysis. which, combined with high night temperatures that shortened the grain-filling period, reduced $Y_{\mathrm{p}}$ (Table 1). Reduced post-silking cumulative solar radiation and concomitant effect on $Y_{\mathrm{P}}$ with late sowing dates has been previously documented for temperate maize by Cirilo and Andrade (1994) and Otegui et al. (1995).
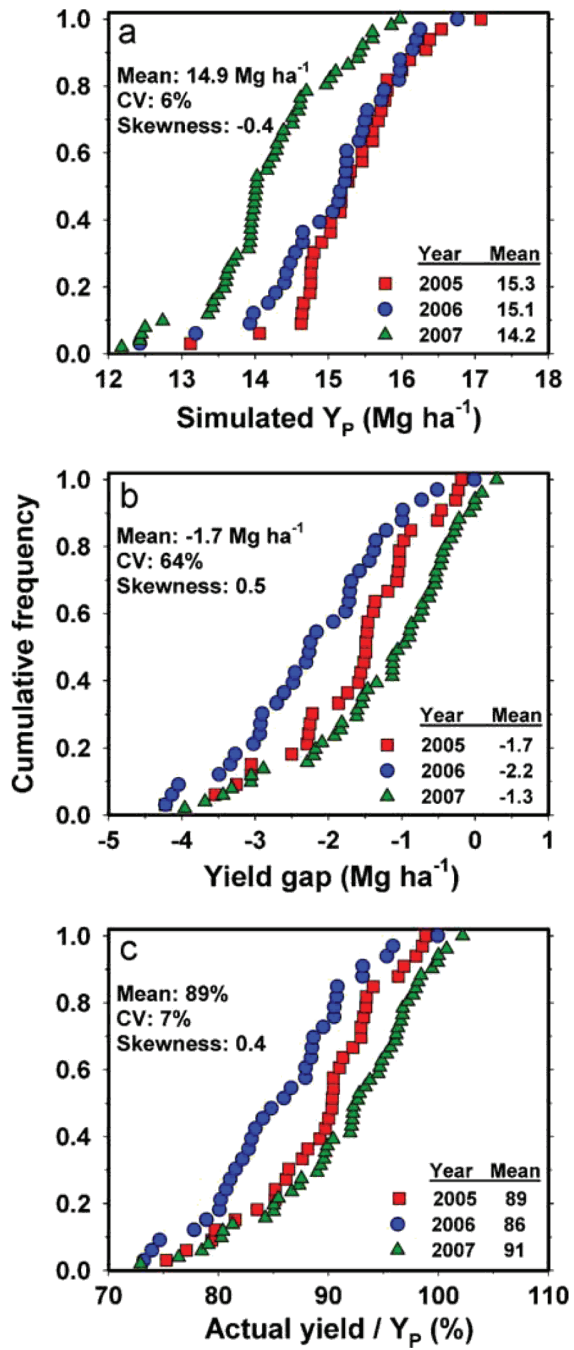

Figure 5. Cumulative frequency distributions of (a) yield potential $\left[Y_{\mathrm{p}}\right]$, (b) yield gap, and (c) actual yield as percentage of $Y_{\mathrm{p}}$ for a subset of maize crops grown in the Tri-Basin Natural Resources District (NRD) in 2005 , 2006, and $2007(n=33,33$, and 57, respectively, representing a subset of 123 field-year observations for which detailed crop management data were obtained). $Y_{\mathrm{p}}$ was estimated using the Hybrid-Maize model in combination with actual weather records and management practices for each field. Yield gap was computed as the difference between actual yield and corresponding simulated $Y_{\mathrm{p}}$. Mean values for each year are shown. 


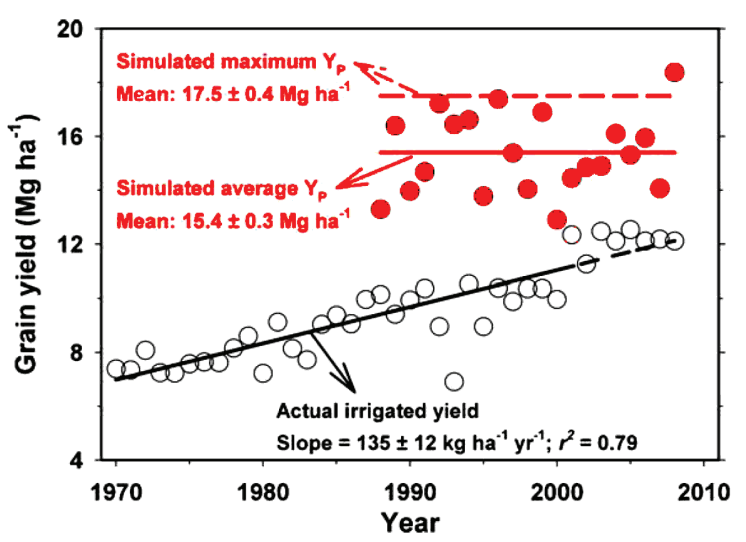

Figure 6. Trends in Tri-Basin NRD (3-county average) irrigated yields (०) and yield potential $\left(Y_{\mathrm{p}}, \bullet\right)$ simulated using Hybrid-Maize model based on average management practices and weather records (19882008). Dashed regression line for actual yield trend corresponds to lack of yield improvement in the last 8-y period. Upper dashed line is maximum simulated $Y_{\mathrm{p}}$ estimated based on the combination of practices that gives highest $Y_{\mathrm{p}}$ as given in Table 3. The slopes of the linear regressions for $Y_{\mathrm{p}}$ were undistinguishable from zero $(p=0.60)$.

Management practices identified to affect $Y_{\mathrm{p}}$ were sowing date, RM, and seeding rate, which as independent variables in a multiple regression model explained 57,81 , and $54 \%$ of the variation on $Y_{\mathrm{P}}$ in 2005, 2006, and 2007, respectively (data not shown). Sensitivity of simulated $Y_{\mathrm{p}}$ to these factors highlights the need for accurate specification of planting date, plant population, and cultivar maturity to arrive at $Y_{\mathrm{P}}$ estimates that reflect current crop management.

Yield gaps averaged $-1.7 \mathrm{Mg} \mathrm{ha}{ }^{-1}$ across years. Interestingly, yield gaps (expressed either as absolute values or percentage of $Y_{\mathrm{p}}$ ) were more closely correlated to $Y_{\mathrm{p}}$ than actual yields $\left(p<0.001, r^{2}=0.46\right.$ and 0.26 , respectively). Average on-farm yield in the Tri-Basin NRD was $89 \%$ of the $Y_{\mathrm{P}}$ simulated using current management practices. Yield potential simulated for the 1986-2008 period using current average farmer management practices and actual weather records in each year averaged $15.4 \pm 0.3 \mathrm{Mg} \mathrm{ha}^{-1}$ (Figure 6). No time trend in simulated $Y_{\mathrm{p}}$ was detected. Actual mean irrigated yield in the Tri-Basin NRD increased at $135 \mathrm{~kg} \mathrm{ha}^{-1} \mathrm{y}^{-1}$ during 1970-2008 period. However, no increase in actual yield has occurred during the last 8-y period of the time series, a period in which farmer's yields have remained relatively stable at $21 \%$ below simulated $Y_{\mathrm{P}}$ (mean: 12.1 $\pm 0.1 \mathrm{Mg} \mathrm{ha}^{-1}$ ). This estimate of yield gap contrasts with the value derived from simulation analysis using field-year specific data (21 vs. $11 \%$, respectively). We speculate the reasons for this difference were due to: (i) specific management practices were used to determine $Y_{\mathrm{P}}$ for the subset of 123 field-years while average management practices were used to estimate Tri-Basin NRD 3-county average $Y_{\mathrm{p}}$; (ii) 100 out of the 123 field-years included in our subset were located in Phelps County, which has a higher average irrigated yield (+0.4 $\mathrm{Mg} \mathrm{ha}^{-1}$ ) than reported for Gosper and Kearney Counties; and (iii) average yield gap derived from Figure 6 for the 2005-2007 period was slightly smaller than the 20012008 average (18vs. $21 \%$ of $Y_{\mathrm{p}}$, respectively).

Changes in current management practices were explored as an option to increase the $Y_{\mathrm{p}}$ ceiling. Simulations using long-term weather records from four meteorological stations inside or near the area of study showed increases in $Y_{\mathrm{p}}$ with higher plant population and longer hybrid RM (Table 3). Compared to average current management practices (sowing date: DOY 117, RM $113 \mathrm{~d}, 7.2$ plants $\left.\mathrm{m}^{-2}\right), Y_{\mathrm{p}}$ increased by 6 and $8 \%$ when RM was extended to $117 \mathrm{~d}$ and plant population increased to 8.6 plants $\mathrm{m}^{-2}$, respectively, and by $13 \%$ when both RM and plant population were increased (mean: $17.5 \pm 0.4 \mathrm{Mg} \mathrm{ha}^{-1}$; see dashed horizontal line in Figure 6). Using $117 \mathrm{~d}$ RM and 8.6 plants $\mathrm{m}^{-2}$ as the reference scenario for simulated maximum $Y_{\mathrm{p}}$, Tri-Basin NRD 3-county average irrigated yields (2001-2008) are $70 \%$ of this benchmark. However, trade-offs associated with adoption of later-maturing hybrids and greater plant population may limit their adoption by farmers, at least under current grain to input price ratios. While extending growth duration through use of a longer maturity hybrid gives higher simulated $Y_{\mathrm{P}}$, it also substantially increases the risk of frost occurrence before physiological maturity and difficulties in harvest operations due to wet weather and snow (Table 3 ). Likewise, yield and economic benefits from higher plant populations can be reduced, or even eliminated, as a result of higher seed costs, higher plant-to-plant variability if intra-row spacing is not uniform, greater incidence of lodging and green snap, and higher susceptibility to heat stress as reported by Yang et al. (2004).

Finally, sowing date effect on simulated $Y_{\mathrm{p}}$ was negligible (Table 3) although actual field data indicated decreasing yields with later planting (Table 2). Based on information provided by local crop consultants, this inconsistency may result from factors not simulated in the Hybrid-Maize model. For example, higher soil temperatures in late plantings may cause rapid soil drying resulting in surface crust formation and higher impedance to root growth which can make more difficult to achieve uniform crop stands. Likewise, late-planted crops are more frequently subjected to weed and disease problems, heat stress episodes during the silking and pollen shed period, and difficulties in harvest operations due to wet weather and early snow.

Table 3. Simulated yield potential $\left(Y_{\mathrm{p}}\right)$ using long-term weather records under different combinations of hybrid relative maturity, plant population density, and sowing date. Average $Y_{\mathrm{P}}$ for current average farmer management practices in the Tri-Basin Natural Resources District (NRD) is in italics. Percentage of years in which frost occurs before physiological maturity is indicated between brackets for each of the relative maturity $\times$ sowing date combinations.

\begin{tabular}{|c|c|c|c|c|c|}
\hline \multirow[t]{2}{*}{ Relative maturity $(\mathrm{d})$} & \multirow[t]{2}{*}{ Plant population $\left(\mathrm{m}^{-2}\right)$} & \multicolumn{4}{|c|}{ Sowing date (day of year) } \\
\hline & & 110 & 117 & 124 & 131 \\
\hline 109 & 7.2 & $14 \cdot 3^{\mathrm{a}}(5)$ & $14.4(5)$ & $14.5(5)$ & 14.5 (14) \\
\hline \multirow[t]{2}{*}{113} & 7.2 & $15 \cdot 3(10)$ & $15 \cdot 4(14)$ & $15 \cdot 4(14)$ & $15 \cdot 5(19)$ \\
\hline & 7.9 & 15.9 & 16.0 & 16.1 & 16.2 \\
\hline \multirow[t]{3}{*}{117} & 7.2 & $16.3(14)$ & $16.3(24)$ & 16.4 (29) & $16.4(33)$ \\
\hline & 7.9 & 16.9 & 16.9 & 17.0 & 17.0 \\
\hline & 8.6 & 17.4 & 17.4 & 17.5 & 17.5 \\
\hline
\end{tabular}

a. Each value is the average of $Y_{\mathrm{P}}$ simulated in four locations inside or near the Tri-Basin NRD. 


\section{Discussion}

The use of on-farm data to identify major management constraints to actual productivity has strengths and weaknesses. A major weakness is that uncontrolled factors across farms can confound effects of management practices on yield. Such confounding can be minimized or avoided if data used in the analysis are of sufficient detail and quality, and include a representative population of farmers over several cropping seasons. These requirements appear to be met by the Tri-Basin NRD database used in the present study. As both federal and state governments increase regulatory pressures on environmental performance of agriculture (e.g., water quality, endangered species, and greenhouse gas emissions), farm reporting requirements for factors affecting environmental performance will likely increase. The result will be greater availability of high quality on-farm data, which provides opportunities to quantify the impact of management practices on yield and efficiencies of water and fertilizer as a compliment to high-cost, multi-year, multi-site field studies.

This study evaluated the impact of current management practices on yield in high-yield irrigated maize systems where actual yields approach $Y_{\mathrm{p}}$. Rotation, tillage system, sowing date, and plant population density were identified as most sensitive factors affecting current yields. The effect of rotation and tillage system on yield of irrigated maize reported here are consistent with published data from long-term rainfed field experiments (Porter et al., 1997; Fischer et al., 2002; Boomsma et al., 2010). While yield of maize after soybean had an overall advantage compared to maize after maize, the benefit of rotation was greater in fields under conservation tillage. Whereas rotation and tillage effects on rainfed yields have multiple causes, including residual $\mathrm{N}$, soil water storage, and disease pressure (Kirkegaard et al., 2008), the explanation for such effects on yield of irrigated maize with generally adequate supply of water and nutrients, and with most other yield-reducing factors effectively controlled, may result from difficulties in crop establishment coupled with greater plant-to-plant variability, $\mathrm{N}$ immobilization in maize residue, and changes in soil biota (Johnson et al., 1992; Gentry et al., 2001; Boomsma et al., 2010).

Farmers in the Tri-Basin NRD had grain yields that were $\sim 35 \%$ greater than Nebraska state average yield, which includes both irrigated and rainfed production. Although they used $20 \%$ higher $\mathrm{N}$ fertilizer rates, $\mathrm{N}$-fertilizer efficiency was $11 \%$ greater than the state average. Extension education in the Tri-Basin NRD encourages use of N "credits" for manure, legume rotations, nitrates applied in irrigation water, and residual soil nitrate as determined by soil testing. As a result, $66 \%$ of reported $\mathrm{N}$-fertilizer rates were within $\pm \mathbf{2 0} \%$ recommended values (data not shown). The results also suggest that Tri-Basin farmers can further improve $\mathrm{N}$ fertilizer efficiency by achieving better congruence between nitrogen supply and crop $\mathrm{N}$ demand. For example, shifting $\mathrm{N}$ application from fall to spring or at planting and greater use of split $\mathrm{N}$-fertilizer or fertigation applications during the growing season, rather than a single large $\mathrm{N}$ application, represent options to achieve better congruence (Cassman et al., 2002).

Time trends in $Y_{\mathrm{p}}$ and actual yield in the Tri-Basin NRD suggest that size of exploitable yield gap for irrigated maize has decreased markedly as average yields are now about $80 \%$ of the $Y_{\mathrm{p}}$ ceiling. Moreover, lack of increase in actual yield since 2001 may represent first indications of a plateau in actual yields as it has been reported for irrigated rice systems in Asia (Cassman et al., 2003). The fact that magnitude of the yield gap in a given year was more closely correlated with $Y_{\mathrm{p}}$ than actual yield suggests that current management practices, focused on maximizing net return, may limit productivity in years when weather conditions support $Y_{\mathrm{p}}$ levels above the long-term average.

The average yield gap reported in this study for irrigated maize in the Tri-Basin NRD based on field-specific management is smaller than Nebraska state-level gap estimated by Duvick and Cassman (1999). This apparent discrepancy is due to differences in the method used to estimate current average $Y_{\mathrm{p}}$. Whereas Duvick and Cassman used contest-winning yields as the $Y_{\mathrm{p}}$ reference, the current study used simulations based on actual weather and management data for a large number of fieldyear observations. The latter accounts for a more representative spectrum of current management practices, soil quality, and weather conditions in estimates of $Y_{\mathrm{p}}$ for farmer's who seek to maximize net return. In contrast, contest-winning yields provide an estimate of the single best combination of management and environment amongst a large number of competing farmers and environments, which is not representative of average $Y_{\mathrm{P}}$ at regional, state, or national scales. Consistent with this discrepancy is the observation that Nebraska contest-winning average irrigated yield reported by Duvick and Cassman (1999) compares well with maximum simulated $Y_{\mathrm{p}}$ estimated in our study using a combination of practices that gives highest $Y_{\mathrm{P}}$ (18.2 vs. 17.5 $\mathrm{Mg} \mathrm{ha}^{-1}$ ).

Results from this study suggest limited potential for further increases in irrigated maize yields without a substantial increase in the current $Y_{\mathrm{p}}$ ceiling. While some of the yield constraints are not amenable to improved management (e.g., excessive heat, terminal frost, warm nighttime temperatures), actual yields may be increased through incremental changes in crop management (e.g., earlier planting dates, soybean-maize rotation instead of continuous maize). Other options might increase $Y_{\mathrm{P}}$ but are operationally difficult or economically risky to adopt with the current grain to input price ratio (e.g., higher plant population and longer maturity). While improving irrigation and nutrient management may reduce excessive inputs amounts and protect environmental quality by enhancing input efficiency, they will have little impact on yield. The same applies to transgenic approaches for higher nitrogen- or water-use efficiencies. Instead, improvement in maize yielding ability is most likely to occur by continued brute-force breeding for grain yield and yield stability across a wide range of environments to produce a continuous stream of improved hybrids, complemented by agronomic research to more fully exploit crop community-level relations and genotype by environment interactions in high-yield environments (Duvick and Cassman, 1999; Denison, 2007).

Acknowledgments - We are grateful to the Tri-Basin NRD board and staff, especially to Tammy Fahrenbruch for providing access to the crop and water use reports and helping with the survey and the many farmers who collaborated in this study. We also thank Drs Albert Weiss, James Specht, and Shashi Verma for useful comments on an earlier version of the paper. Support for this project comes from the Water, Energy and Agriculture Initiative, made possible with funding from the Nebraska Corn Board, the Nebraska Soybean Board, the Agricultural Research Division (ARD) at the University of Nebraska-Lincoln (UNL) and Nebraska Public Power District through the Nebraska Center for Energy Sciences Research at UNL. The senior author wishes also to acknowledge financial support from the Fulbright Program, UNL, and the ARD for his graduate assistantship.

\section{References}

Abeledo, L.G., Savin, R., Slafer, G.A., 2008. Wheat productivity in the Mediterranean Ebro Valley: analyzing the gap between attainable and potential yield with a simulation model. Eur. J. Agron. 28, 541-550.

Boomsma, C.R., Santini, J.B., West, T.D., Brewer, J.C., McIntyre, L.M., Vyn, T.J., 2010. Maize grain yield responses to plant height variability resulting from crop rotation and tillage in a long term experiment. Soil Tillage Res. 106, 227-240.

Cassman, K.G., 1999. Ecological intensification of cereal production systems: yield potential, soil quality, and precision agriculture. Proc. Natl. Acad. Sci. U.S.A. 96, 5952-5959. 
Cassman, K.G., Dobermann, A., Walters, D.T., 2002. Agroecosystems, nitrogen-useefficiency, and nitrogen management. Ambio 31, 132-140.

Cassman, K.G., Dobermann, A., Walters, D.T., Yang, H.S., 2003. Meeting cereal demand while protecting natural resources and improving environmental quality. Annu. Rev. Environ. Resour. 28, 315-358.

Cassman, K.G., Liska, A.J., 2007. Food and fuel for all: realistic or foolish? Biofuels Bioprod. Biorefin. 1, 18-23, http://www3.interscience.wiley. com/cgibin/fulltext/114283521/PDFSTART

Cirilo, A.G., Andrade, F.H., 1994. Sowing date and maize productivity: I. Crop growth and dry matter partitioning. Crop Sci. 34, 1039-1043.

Denison, R.F., 2007. When can intelligent design of crops by humans outperform natural selection? In: Spiertz, J.H.J., Struik, P.C., van Laar, H.H. (Eds.), Scale and Complexity in Plant Systems Research, Gene-Plant-Crop Relations. Springer, The Netherlands, pp. 287-302.

Dobermann, A., Ferguson, R.B., Hergert, G.W., Shapiro, C.A., Tarkalson, D., Walters, D.T., Wortmann, C.S., 2006. Nitrogen response in highyielding corn systems of Nebraska. In: Schlegel, A.J. (Ed.), Proceedings of the Great Plains Soil Fertility Conference. Denver, CO. Kansas State University, Manhattan, KS, pp. 50-59.

Duvick, D.N., Cassman, K.G., 1999. Post-green revolution trends in yield potential of temperate maize in the North-Central United States. Crop Sci. 39, 1622- 1630.

Evans, L.T., 1993. Crop Evolution, Adaptation, and Yield. Cambridge University Press, Cambridge, UK.

Fischer, R.A., Santiveri, F., Vidal, I.R., 2002. Crop rotation, tillage and crop residue management for wheat and maize in the sub-humid tropical highlands. II. Maize and system performance. Field Crops Res. 79, 123-137.

Franke, R., Nielson, G., 1980. Smooth interpolation of large sets of scattered data. Int. J. Numer. Meth. Eng. 15, 1691-1704.

Gentry, L.E., Below, F.E., David, M.B., Bergerou, J.A., 2001. Source of the soybean N credit in maize production. Plant Soil 236, 175-184.

Grassini, P., Yang, H., Cassman, K.G., 2009. Limits to maize productivity in Western Corn-Belt: a simulation analysis for fully-irrigated and rainfed conditions. Agr. Forest Meteorol. 149, 1254-1265.

Grassini, P., Yang, H., Irmak, S., Thorburn, J., Burr, C., Cassman, K.G., 2011. High-yield irrigated maize in the Western U.S. Corn Belt. II. Irrigation management and crop water productivity. Field Crops Res. 120, 133-141.

Hubbard, K.G., 1994. Spatial variability of daily weather variables in the high plains of the USA. Agr. Forest Meteorol. 68, 29-41.

Johnson, N.C., Copeland, P.J., Crookston, R.K., Pfleger, F.L., 1992. Mycorrhizae: possible explanation for yield decline with continuous corn and soybean. Agron. J. 84, 387-390.

Klein, R.N., Wilson, R.K., 2010. Nebraska Crop Production Budgets. Nebguide EC872. University of Nebraska Cooperative Extension Service, Lincoln; online @ http://cropwatch.unl.edu/web/economics/ budgets

Kirkegaard, J., Christen, O., Krupinsky, J., Layzell, D., 2008. Break crop benefits in temperate wheat production. Field Crops Res. 107, $185^{-195}$.

Lobell, D.B., Cassman, K.G., Field, C.B., 20o9. Crop yield gaps: their importance, magnitude, and causes. Annu. Rev. Environ. Resour. 34, $1-26$.
Lobell, D.B., Ortiz-Monasterio, J.I., Asner, G.P., Naylor, R.L., Falcon, W.P., 2005. Combining field surveys, remote sensing, and regression trees to understand yield variations in an irrigated wheat landscape. Agron. J. 97, 241-249.

Loomis, R.S., Connor, D.J., 1992. Crop Ecology. Productivity and Management in Agricultural Systems. Cambridge University Press, Cambridge.

Mercau, J.L., Sadras, V.O., Satorre, E.H., Messina, C., Balbi, C., Uribelarrea, M., Hall, A.J., 2001. On-farm assessment of regional and seasonal variation in sunflower yield in Argentina. Agric. Syst. 67, 83-103.

Nebraska Association of Resources Districts, 2010; online @ http://www. nrdnet.org/

Nebraska Department of Natural Resources (DNR), 2010. Registered groundwater wells by Natural Resources District; online @ http:// dnrdata.dnr.ne.gov/wellssql/Summary.asp?type $=$ nrd

Otegui, M.E., Nicolini, M.G., Ruiz, R.A., Dodds, P.A., 1995. Sowing date effects on grain yield components for different maize genotypes. Field Crops Res. 87, 29-33.

Porter, P.M., Lauer, J.G., Lueschen, W.E., Ford, J.H., Hoverstad, T.R., Oplinger, E.S., Crookston, K.R., 1997. Environment affects the corn and soybean rotation effect. Agron. J. 89, 441-448.

Sadras, V., Roget, D., O'Leary, G.O., 2002. On-farm assessment of environmental and management constraints to wheat yield and efficiency in the use of rainfall in the Malle. Aust. J. Agric. Res. 53, 587-598.

Tollenaar, M., Lee, E.A., 2002. Yield potential, yield stability and stress tolerance in maize. Field Crops Res. 75, 161-169.

Tri-Basin Natural Resources District, 2010; online @ http://www.tribasinnrd.org/

USDA-Economic Research Service (ERS). Adoption of genetically engineered crops in the U.S.: corn varieties; online @ http://www.ers. usda.gov/Data/BiotechCrops/ExtentofAdoptionTable1.htm

USDA-Natural Resources Conservation Service (NRCS). Soil survey geographic (SSURGO) database for Gosper, Kearney, and Phelps counties, Nebraska; online @ http://soildatamart.nrcs.usda.gov

USDA-National Agricultural Statistics Service (NASS), 1970-2008. Crops U.S. state and county databases. Washington DC; online @ http:// www.nass.usda.gov/index.asp

Verma, S.B., Dobermann, A., Cassman, K.G., Walters, D.T., Knops, J.M., Arkebauer, T.J., Suyker, A.E., Burba, G.G., Amos, B., Yang, H., Ginting, D., Hubbard, K.G., Gitelson, A.A., Walter-Shea, E.A., 2005. Annual carbon dioxide exchange in irrigated and rainfed maize-based agroecosystems. Agr. Forest Meteorol. 131, 77-96.

Wiese, M.V., 1982. Crop management by comprehensive appraisal of yield determining variables. Annu. Rev. Phytopathol. 20, 419-432.

Yang, H.S., Dobermann, A., Cassman, K.G., Lindquist, J.L., Walters, D.T., Arkebauer, T.J., Cassman, K.G., 2004. Hybrid-Maize: a maize simulation model that combines two crop modelling approaches. Field Crops Res. 87, 131-154.

Yang, H.S., Dobermann, A., Cassman, K.G., Walters, D.T., 2006. HybridMaize (ver. 2006). A Simulation Model for Corn Growth and Yield. Nebraska Cooperative Extension CD 9, University of Nebraska-Lincoln, Lincoln, NE; online @ http://www.hybridmaize.unl.edu/UserGuide.htm 